\title{
HUBUNGAN SIKAP DAN MOTIVASI KERJA DENGAN KINERJA KADER POSYANDU \\ KASUS: DESA COPER DAN DESA KUTUWETAM, KECAMATAN JETIS, KABUPATEN PONOROGO
}

\section{Correlation of Attitude and Motivation Working with The Perfomance of Posyandu Cadres Case: Coper Village and Kutuwetan Village, Jetis Subdistrict, Ponorogo}

\author{
Ade Sintya Kusumawardani ${ }^{1)}$ dan Pudji Muljono ${ }^{1)}$ \\ ${ }^{1)}$ Departemen Sains Komunikasi dan Pengembangan Masyarakat, Fakultas Ekologi Manusia \\ Institut Pertanian Bogor, Dramaga Bogor, 16680, Indonesia \\ Email: adesintyak@gmail.com; pudjim@apps.ipb.ac.id
}

\begin{abstract}
Health development is important to build the quality of people in a country, one of them is based health service public participation. Cadres would be seen attitude and her motivation inbeing healthcare community. A affectiver of cadre posyandu can be seen from cognitive aspects, affective, and conative. Attitude and motivation will be connected with the perfomance of Posyandu cadres such as cooperation, utilization of time, attendace rates, quality of work, and quantity of work. This paper aims to find out correlation of attitude and motivation Posyandu participant with the perfomance of Posyandu cadres. This research used a quantitative approach support by qualitative data. Methods used in research this is the method survey with respondents as many as 35 people. The resulut of this research, there are significant corelation between attitude with the motivation work cadres is 0,390, and there are corelation between attitude with the perfomance cadres is 0,322 and there are corelation between motivation work with the perfomance cadres is 0,375.
\end{abstract}

Keyword: attitude, cadres of Posyandu, motivation, perfomance.

\begin{abstract}
ABSTRAK
Pembangunan kesehatan merupakan hal yang penting dalam membangun kualitas manusia di suatu negara salah satunya dengan melakukan pelayanan kesehatan berbasis partisipasi masyarakat. Sikap kader terhadap kegiatankegiatan Posyandu mencakup aspek kognisi, afeksi, dan konasi. Aspek motivasi kerja mencakup motivasi eksternal dan internal. Sikap dan motivasi kerja ini akan dihubungkan dengan kinerja kader Posyandu seperti kerjasama, pemanfaatan waktu, tingkat kehadiran, kualitas kerja, dan kuantitas kerja. Tulisan ini bertujuan untuk mengetahui hubungan sikap dan motivasi dengan kinerja kader. Penelitian ini menggunakan pendekatan kuantitatif yang didukung dengan data kualitatif. Metode yang digunakan dalam penelitian ini adalah metode survey dengan responden sebanyak 35 orang. Hasil penelitian ini menunjukkan, terdapat hubungan signifikan antara sikap dengan motivasi kerja kader sebesar 0,390 serta hubungan antara sikap denga kinerja sebesar 0,322 dan terdapat hubungan antara motivasi kerja dengan kinerja sebesar 0,375.
\end{abstract}

Kata kunci: kinerja, kader Posyandu, motivasi, sikap.

\section{PENDAHULUAN}

Pembangunan kesehatan yang merupakan salah satu program proiritas dalam mewujudkan agenda pembangunan nasional mempunyai arah kebijakan yaitu meningkatkan akses masyarakat terhadap pelayanan kesehatan masyarakat yang ditandai dengan meningkatkan angka harapan bayi, ibu melahirkan dan juga meningkatkan status gizi masyarakat (Darmawan 2009). Depkes RI (2011) memperkirakan Indonesia akan mengalami pertambahan lanjut usia terbesar di dunia antara tahun 1990 sampai 2025 yaitu sebesar $414 \%$, yang merupakan angka paling tinggi di dunia. Hal ini menunjukkan bahwa pembangunan kesehatan merupakan hal penting 
dalam pembangunan kualitas manusia pada suatu negara.

Posyandu merupakan salah satu bentuk pendekatan partisipasi masyarakat dibidang kesehatan yang dikelola oleh kader Posyandu yang telah mendapatkan pendidikan dan pelatihan dari Puskesmas (Simanjuntak 2012). Posyandu dikelola oleh puskesmas tidak lepas dengan peran masyarakat melalui adanya kader. Peran kader Posyandu untuk mendekatkan kebutuhan pelayanan kesehatan bagi masyarakat. Pemendagri No 7 tahun 2007 juga menjelaskan bahwa kader pemberdayaan masyarakat adalah anggota masyarakat desa/kelurahan yang mampu menggerakkan masyarakat untuk berpartisipasi dalam pemberdayaan masyarakat dan pembangunan partisipatif.

Kinerja merupakan hasil kerja secara kualitas dan kuantitas yang dicapai oleh seseorang pegawai dalam melaksanakan tugasnya sesuai dengan tanggung jawab yang diberikan (Simanjuntak, 2012). Dalam hal ini kader merupakan salah satu bentuk partisipasi masyarakat dalam bidang kesehatan yang mudah diakses oleh masyarakatmasyarakat tertentu. Selain itu, kader Posyandu memiliki peran yang sangat penting yaitu memberikan pelayanan kesehatan yang mampu menjangkau masyarakat dan melakukan tatap muka lebih sering dibandingkan dengan petugas kesehatan lainnya.

Selama menggunakan pelayanan Posyandu, akan terlihat bagaimana sikap kader dalam melayani masyarakat. Listiarini (2012) juga mengungkapkan jika sikap sangat terkait dengan kepercayaan dan keputusan seseorang. Sikap seseorang terhadap suatu obyek atau subyek dapat berupa positif atau negatif. Manifestasi sikap terlihat dari tanggapan seseorang apakah ia menerima atau menolak, setuju atau tidak setuju, terhadap obyek atau subyek. Pelayanan yang baik akan membentuk sikap kader dalam menjalankan perannya di Posyandu.

Selain itu, setiap manusia memiliki berbagai kebutuhan dalam hidupnya, termasuk dalam kebutuhan kesehatan. Adanya kebutuhan ini akan menyebabkan tekanan kepada individu sehingga ada dorongan pada dirinya untuk melakukan tindakan. Menurut Sumarwan (2011), motivasi muncul karena adanya kebutuhan yang dirasakan individu. Maka dari itu kebutuhan tersebut muncul karena individu merasakan adanya ketidaknyamanan antara seharusnya dirasakan dan yang sesungguhnya dirasakan. Ketidaknyamanan itu yang akan memicu seseorang bertindak termasuk kader Posyandu.

Simanjuntak (2012) memaparkan bahwa krisis ekonomi yang melanda Indonesia turut memengaruhi aktivitas Posyandu, hal ini terlihat dengan adanya penurunan aktivitas kader di Posyandu dan terlihat dari banyaknya kader yang drop out. Selain itu kurangnya pembinaan kepada kader Posyandu juga menyebabkan melemahnya fungsi kader sebagai pelayanan kesehatan terdekat dengan masyakat. Akibatnya, banyaknya kader yang memutuskan untuk berhenti dari pekerjaannya dan membuat keberadaan dari Posyandu makin memburuk dan bahkan tidak aktif kembali. Hal ini sesuai dengan laporan Dinkes Jawa Timur (2012) Kabupaten Ponorogo hanya mencapai target $72,01 \%$ dari target $85 \%$ dibidang penimbangan balita disebabkan oleh melemahnya peran kader dalam mensosialisasi kegiatan dalam Posyandu.

Berdasarkan hal-hal diatas, rumusan masalah penelitian yang akan dikaji sebagai berikut:

1. Bagaimana Hubungan sikap dengan motivasi kerja kader Posyandu?

2. Bagaimana hubungan sikap dengan kinerja kader Posyandu?

3. Bagaimana hubungan motivasi kerja dengan kinerja kader Posyandu?

\section{PENDEKATAN TEORITIS}

\section{Sikap}

Sikap merupakan konsep yang paling penting dalam psikologi sosial, karena sikap adalah salah satu unsur kepribadian yang memiliki pengaruh besar dalam diri seseorang. Menurut Harihanto (2001) juga menyatakan bahwa sikap adalah kecenderungan seseorang untuk mengetahui, merasakan, dan bertindak terhadap obyek yang disikapi dan terorganisir di dalam suatu sistem yang berlangsung secara terus menerus. Hal ini menunjukkan bahwa sikap merupakan reaksi tertutup dan umumnya mencerminkan opini atau 
pendapat seseorang secara implisit, tetapi sebaliknya apa yang dinyatakan seseorang belum tentu menggambarkan sikap atau attitude yang sebenarnya. Sikap bukanlah tingkah laku melainkan kecenderungan untuk merasa, berpikir, bertindak, dan bertingkah laku dengan cara-cara tertentu terhadap obyek sikap baik berupa benda, orang, kelompok, tempat, situasi ataupun gagasan. Menurut Harihanto (2001) sikap memiliki 3 komponen yaitu kognisi, afeksi, dan konasi. Ketiga hal tersebut akan dijelaskan sebagai berikut:

\section{Kognisi}

Komponen kognisi mencakup penilian individu terhadap suatu obyek atau subyek. Informasi yang masuk ke dalam otak manusia, melalui proses analisis, sintesis, dan evaluasi akan menghasilkan nilai baru yang akan diakomodasi atau diasimilaksikan dengan pengetahuan yang telah ada di dalam otak manusia.

\section{Afeksi}

Komponen afeksi berkenaan dengan emosional dan faktor sosio psikologis, aspek ini menyangkut masalah emosional subyektif seseorang terhadap suatu obyek sikap. Secara umum komponen ini disamakan dengan perasaan yang dimiliki obyek tertentu.

\section{Konasi}

Komponen ini berkenaan dengan keinginan individu untuk melakukan perbuatan sesuai dengan keyakinan dan keinginannya. Konasi juga merupakan bentuk reaksi dari emosi dan kesadaran yang dia miliki. Pada tahap ini kader akan menunjukkan menerima atau menolak pada suatu reaksi yang sedang dihadapinya. Oleh sebab itu, pengukuran konasi ini nampak atau dapat terlihat.

\section{Motivasi}

Menurut Wijaya (2013), proses terjadinya motivasi yaitu suatu kebutuhan dengan keadaan internal dimana menimbulkan hasil-hasil tertentu dimana suatu kebutuhan terpuaskan makan akan menciptakan tegangan yang merangsang dorongan-dorongan di dalam individu tersebut. Motivasi pada diri seseorang merupakan proses dinamis, karena dapat diaktifkan dari sumber yang berbeda tanpa disadari, stimulus yang masa dapat mengaktifkan motivasi yang berbeda tergantung pada situasi dan diri seseorang. Motivasi yang disadari atau tidak akan memengaruhi pikiran, perasaan, dan perilaku seseorang.

Pengaruh adanya motivasi nyatanya tidak terlepas dari faktor-faktor yang memengaruhi. Penelitian Sengkey et.al (2015) menjelaskan bahwa ada beberapa faktor pendorong motivasi yang terdiri dari motivasi intrinsik dan ekstrinsik. Motivasi intrinsik terdiri dari faktor umur, tingkat pendidikan, lama pekerjaan, lama menjadi kader, minat dan kemampuan sedangkan motivasi ekstrinsik meliputi fasilitas posyandu, pelatihan kader, pembinaan kader, insentif dan dukungan masyarakat yang diberikan kepada kader. Berbeda dengan Suhartini (2014) juga mengatakan ada dua faktor ekstrinsik dan intrinsik. Pada faktor ekstrinsik membahas mengenai penggajian, keamanan kerja, kondisi kerja, status pekerjaan, kebijakan dan administrasi, kualitas pengendalian teknik, dan kualitas teman sejawat. Faktor intrinsik antara lain pengalaman, tanggung jawab, kemajuan dan peningkatan, serta pekerjaan itu sendiri.

\section{Kinerja}

Keberhasilan suatu organisasi dipengaruhi oleh kinerja yang baik. Mangkunegara (2007) juga menjelaskan bahwa kinerja merupakan hasil kerja secara kualitas dan kuantitas yang dicapai oleh seorang pegawai dalam melakasanakan tugasnya sesuai dengan tanggung jawab yang diberikan kepadanya. Teori tersebut sejalan dengan pendapat Simanjuntak (2012) yang mengatakan bahwa kinerja merupakan hasil kerja secara kualitas dan kuantitas yang dicapai oleh seorang kader dalam melaksanakan tugasnya sesuai dengan tanggung jawab yang diberikan kepadanya. Hal ini menunjukkan bahwa kinerja bukan sifat atau karakteristik individu, melainkan kemampuan kerja yang ditunjukkan melalui proses atau cara bekerja dan hasil yang di dicapai.

Setiap kader memiliki kinerja yang berbeda-beda. Kinerja merupakan hasil atau tingkatan keberhasilan seseorang selama periode tertentu dalam proses pelaksanaan tugasnya secara keseluruhan yang dibandingkan dengan beberapa kemungkinan seperti standar hasil kerja, 
target/sasaran/kriteria yang sebelumnya telah ditentukan atau disepakati bersama (Rivai dan Basri 2005). Mathis dan Jackson (2002) menjelaskan kinerja merupakan seberapa banyak kontribusi yang dilakukan untuk organisasi yaitu dalam:

1. Kuantitas kerja, standart yang digunakan untuk membandingkan antara besarnya volume kerja dengan kemampuan sebenarnya.

2. Kualitas kerja, standar untuk menekankan pada mutu kerja yang dihasilkan dibandingkan volume kerja.

3. Pemanfaatan waktu, merupakan penggunaan masa kerja yang disesuaikan dengan kebijaksanaan organisasi.

4. Tingkat kehadiran, merupakan alat ukur sejauh mana anggota memberikan kontribusi yang optimal kepada organisasi.

5. Kerjasama, merupakan keterlibatan seluruh pegawai untuk mencapai suatu target yang sudah ditetapkan akan memengaruhi keberhasilan bagian yang diawasi. Suatu kerjasama akan terbentuk apabila pemimpin dan anggotanya mampu memotivasi dengan baik.

\section{Kerangka Pemikiran}

Seorang kader mampu menjalankan perannya karena terdapat dorongan atas sikap dan motivasi. Ukuran sikap pada kader merupakan salah satu bentuk kepribadian yang memiliki pengaruh yang besar dalam dirinya. Pengaruh ini akan membentuk bagaimana merespon suatu obyek yang diamati dan difikirkan. Sesuai dengan penelitian oleh Wijaya (2013) yang menjelaskan bahwa sikap akan menentukan keaktifannya dalam pelaksanaan kegiatan Posyandu. Kusumawati (2013) juga menjelaskan bahwa sikap mampu untuk mengukur bagaimana kinerja dari seseorang. Sikap seorang kader akan terlihat selama pelaksanaan kegiatan Posyandu berlangsung. Menurut Harihanto (2001) sikap tersebut mencakup aspek kognisi, afeksi dan konasi. Pada setiap tahapan sikap, kader Posyandu akan mengevaluasi mulai dari pelayanan yang dia berikan, pengetahuan mengenai kesehatan masyarakat, cara kader melayani peserta Posyandu, kerjasama antar kader Posyandu. Aspek kognisi mencakup bagaimana pengetahuan kader mengenai kualitas dan kuantitas kinerja kader Posyandu. Hal ini bertujuan untuk mengetahui sejauh mana kader Posyandu memahami yang akan dilakukan selama kegiatan Posyandu berlangsung. Selanjutnya pada aspek afeksi, kader Posyandu akan mengevaluasi bagaimana manfaat dari Posyandu tersebut. Hasil-hasil dari kegiatan Posyandu seperti konsultasi gizi, imunisasi, penyuluhan, pengecekan ibu hamil, penimbangan maupun pemberian vitamin apakah sudah mereka sampaikan untuk para peserta Posyandu yang hadir. Selain itu aspek afeksi juga menentukan peserta mau melakukan apa yang para kader rekomendasikan. Aspek terakhir yaitu aspek konasi dimana para kader akan dinilai apakah rekomendasi atau informasi-informasi yang diberikan kader Posyandu sudah dilakukan. Penilaian aspek konasi ini sudah pada tahapan kebiasaan dimana para peserta apakah sudah terbiasa dengan kegiatan-kegiatan Posyandu dan merasa pelayanan yang diberikan kader sudah sesuai dengan apa yang mereka inginkan.

Dorongan kebutuhan peserta Posyandu akan membedakan motivasi-motivasi yang dituju. Suryatini (2001) menjelaskan bahwa faktor yang memengaruhi kinerja kader Posyandu adalah dengan adanya motivasi. Motivasi ini akan menentukan bagaimana sikap dan kinerja yang akan dilakukan kader. Wijaya (2013) juga memaparkan bahwa tingginya motivasi seseorang akan memengaruhi keaktifan individu tersebut dalam kegiatan yang melibatkan dirinya. Beberapa teori menjelaskan bahwa motivasi dibentuk oleh faktor intrinsik dan faktor ekstrinsik. Berdasarkan beberapa teori mengenai motivasi disimpulkan bahwa faktor intrinsik mencakup pengalaman, tanggung jawab, dan kepuasan intrinsik, sedangkan pada faktor ekstrinsik mencakup kondisi kerja, fasilitas Posyandu, hubungan sosial, insentif, dan pelatihan. Hal ini didasari oleh hasil penelitian yang memiliki pengaruh paling besar dalam penentuan motivasi kerja seseorang. 


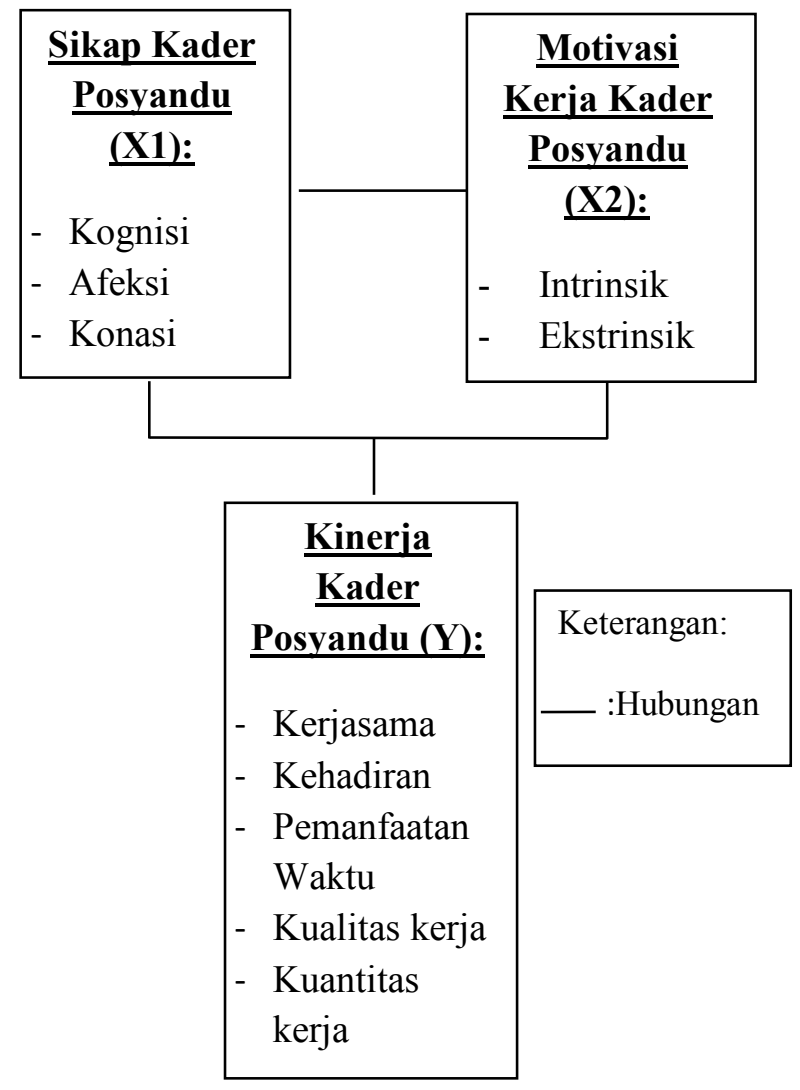

Gambar 1 Kerangka pikir hubungan sikap dan motivasi kerja dengan kinerja kader Posyandu

Keberhasilan Posyandu dapat diukur dari tingkat kinerja kader Posyandu maupun bidan desa. Kinerja kader mencakup seluruh kegiatan yang ada dalam Posyandu. Penelitian oleh Simanjuntak (2012) menjelaskan bahwa kinerja kader dapat dilihat bila kader mampu melaksanakan tugas dan tanggung jawab yang baik. Tugas dan tanggung jawab ini berdasarkan faktor yang mendorong seperti sikap dan motivasi kader. Ada beberapa variabel yang dapat menilai kinerja kader antara lain kerjasama, tingkat kehadiran, pemanfaatan waktu, kualitas kerja dan kuantitas kerja. Penilaian kinerja ini tidak dilakukan oleh kader namun orang-orang yang mampu menilai kinerja kader seperti halnya dalam organisasi yang mampu menilai adalah atasannya. Dalam kerjasama mencakup bagaimana hubungan antara satu kader dengan kader lainnya, dan pembagian peran pada setiap kader. Tingkat kehadiran kader juga merupakan hal yang penting dalam berjalannya kegiatan Posyandu. Kader yang selalu aktif datang dapat membuat kegiatan Posyandu berjalan dan peserta Posyandu akan lebih aktif pula untuk hadir. Peserta Posyandu yang hadir dalam kegiatan-kegiatan Posyandu akan cenderung melihat berapa lama waktu yang digunakan. Biasanya para peserta Posyandu akan cenderung jenuh jika waktu yang digunakan terlalu lama dan tidak efisien. Mutu kerja atau kualitas kerja juga merupakan variabel dalam kinerja. Kualitas kerja sendiri menjelaskan mengenai bagaimana proses kader dalam menjalankan perannya. Proses ini lebih kepada kemampuan kader dalam menghadapi situasi dan cara menyelesaikannya. Berbeda dengan kuantitas kerja, lebih kepada hasil yang diberikan. Pelayanan yang diberikan kader apakah sudah maksimal dan mampu bermanfaat untuk para peserta kader. Penilaian kinerja kader ini dapat mengukur pula apakah Posyandu sudah berhasil sesuai dengan tujuannya.

\section{Hipotesis Penelitian}

1. Diduga terdapat hubungan antara sikap dan motivasi kerja kader Posyandu.

2. Diduga terdapat hubungan antara sikap dengan kinerja kader Posyandu.

3. Diduga terdapat hubungan antara motivasi kerja dengan kinerja kader Posyandu.

\section{PENDEKATAN LAPANG}

Penelitian ini menggunakan pendekatan kuantitatif yang didukung dengan data kualitatif. Metode yang digunakan adalah penelitian survei dimana pengumpulan data menggunakan kuesioner sebagai alat yang ditunjukkan pada responden dari suatu populasi (Singarimbun dan Effendi 2008).

Penelitian mengenai hubungan sikap dan motivasi dengan kinerja Kader Posyandu ini dilakukan di dua desa yaitu Desa Coper dan Desa Kutuwetan, Kecamatan Jetis, Kabupaten Ponorogo. Desa Coper memiliki 4 pos Posyandu yaitu Posyandu Anggrek, Posyandu Sedap Malam, Posyandu Mangga, dan Posyandu Menco. Desa Kutuwetan juga memiliki 3 pos Posyandu yaitu Posyandu Mawar Merah, Posyandu Mawar Putih, dan Posyandu Mawar Jingga. Posyandu-Posyandu tersebut tersebar untuk masing-masing dukuh di setiap desa. Penelitian ini dilakukan secara purposive (sengaja) di kedua desa. 
Data yang digunakan dalam penelitian ini terdiri dari data primer dan data sekunder. Data primer yang ingin didapatkan berupa data langsung dari responden dan informan melalui survei, observasi serta wawancara. Data sekunder diperoleh melalui dokumen-dokumen tertulis di kantor desa, tujuh Posyandu desa, dan Puskesmas kecamatan. Selain itu adanya data pendukung lainnya berupa hasil penelitian, jurnal-jurnal penelitian yang berkaitan dengan peneliti.

Unit analisis yang diambil adalah individu yang berpartisipasi menjadi kader Posyandu. Responden akan diwawancarai sesuai dengan kuesioner dan jawaban akan disesuaikan dengan pilihan yang sudah ditentukan dalam kuesioner.'Jumlah sampel yang digunakan sebanyak 35 responden yaitu kader-kader dari Desa Coper dan Desa Kutuwetan. Teknik pengambilan sampel ini dengan menggunakan sensus. Informan yang digunakan dalam penelitian ini adalah bidan desa, kepala desa, tokoh masyarakat dan beberapa masyarakat yang menggunakan pelayanan Posyandu dengan menggunakan teknik wawancara mendalam dan teknik bola salju (snowball) untuk memperkuat data kuantitatif.

Dua jenis data digunakan dalam penelitian ini yaitu data kuantitatif dan data kualitatif. Data kuantitatif diolah menggunakan aplikasi Microsoft Excel 2007 dan SPSS 21.0. Data akan dianalisis dengan menggunakan tabel frekuensi, tabulasi silang, grafik ataupun diagram untuk melihat data awal responden untuk masingmasing variabel secara tunggal dengan menggunakan aplikasi Microsoft Excel 2007. SPSS 21.0 digunakan untuk uji statistik yang akan menggunakan uji korelasi Rank Spearman untuk menganalisis hubungan antara sikap, motivasi kerja dan kinerja kader Posyandu. Jenis data kualitatif akan dianalisis melalui tiga tahapan yaitu reduksi data, penyajian data, dan verifikasi.

\section{HASIL DAN PEMBAHASAN}

\section{Karakteristik Responden}

\section{Umur}

\footnotetext{
${ }^{1}$ Menuru Dwiatmaja (2012) dewasa muda (20-39 tahun), dewasa madya (31-49 tahun), dewasa lanjut (50-75 tahun).
}

Berdasarkan hasil penelitian di lapang, sebanyak $43 \%$ kader berumur $41-50$ tahun, 29\% Kader berumur 31-40 tahun, 20\% kader berumur diatas 50 tahun dan $8 \%$ kader yang berumur 30 tahun. Penyebaran terbesar terdapat pada kisaran umur 41-50 tahun yang termasuk kedalam dewasa madya $^{1}$. Usia termuda kader yaitu 27 tahun dengan usia tertua kader yaitu 61 tahun.

Tabel 1 Jumlah dan persentase responden (jiwa) menurut tingkat umur di Desa Coper dan Desa Kutuwetan tahun 2017.

\begin{tabular}{llcc}
\hline No & \multicolumn{1}{c}{ Umur } & Jumlah & Persentase (\%) \\
\hline 1 & $\leq 30$ tahun & 3 & 8 \\
2 & $31-40$ & 10 & 43 \\
& tahun & & \\
3 & $41-50$ & 15 & 29 \\
& tahun & 7 & 20 \\
4 & $\geq 51$ tahun & 75 & 100 \\
\hline
\end{tabular}

Penyebaran umur juga menunjukkan berapa lama kader berkontribusi untuk desa melalui perannya sebagai kader. Hampir sebagian kader lama menjadi kader dan berumur diatas 50 tahun. Hal ini menunjukkan bahwa kader sudah melaksanakan tugas dan tanggung jawabnya sebagai kader sejak usia dewasa muda.

\section{Pendidikan}

Mayoritas kader di Desa Coper dan Kutuwetan sudah tamat SMP (Sekolah Menengah Pertama) dan beberapa kader melanjutkan sekolah hingga tingkat SMA (Sekolah Menengah Atas). Berdasarkan hasil lapang menunjukkan bahwa 69\% kader tamat SMA atau lebih besar dari tamatan SMP sebesar 31\%. Tingkat pengetahuan kader sudah cukup baik dalam pemahaman materi baik secara lisan maupun tertulis. Kemampuan dalam menjalankan tugas-tugasnya juga sudah cukup baik dan dimengerti oleh para kader. Kenyataanya pendidikan merupakan hal penting dalam menunjang pengetahuan seseorang. 
Kurangnya keterampilan seseorang juga disebabkan oleh tingkat pendidikan yang rendah.

Tabel 2 Jumlah dan persentase responden (jiwa) menurut tingkat pendidikan di Desa Coper dan Desa Kutuwetan tahun 2017

\begin{tabular}{clcc}
\hline No & $\begin{array}{c}\text { Tingkat } \\
\text { Pendidikan }\end{array}$ & Jumlah & $\begin{array}{c}\text { Persentase } \\
(\%)\end{array}$ \\
\hline 1 & SMP & 11 & 31 \\
2 & SMA & 24 & 69 \\
\hline & Total & 35 & 100 \\
\hline
\end{tabular}

\section{Pekerjaan}

Pekerjaan dalam karakteristik responden merupakan pekerjaan diluar dari perannya sebagai kader. Hampir seluruh responden tidak memiliki pekerjaan diluar kader atau hanya menjadi ibu rumah tangga. Pekerjaan ibu rumah tangga mencapai $63 \%$ yang merupakan frekuensi tertinggi diantara pekerjaan yang lain. Pekerjaan kedua terbanyak setelah rumah tangga adalah petani yaitu $14 \%$, kemudian wirausaha $11 \%$, buruh tani sebanyak 9\% dan PNS sebanyak 3\%..

Tabel 3 Jumlah dan persentase responden (jiwa) menurut jenis pekerjaan di Desa Coper dan Desa Kutuwetan tahun 2017.

\begin{tabular}{llcc}
\hline No & \multicolumn{1}{c}{ Pekerjaan } & Jumlah & $\begin{array}{c}\text { Persentase } \\
(\%)\end{array}$ \\
\hline 1 & Ibu Rumah & 22 & 63 \\
& Tangga & 1 & 3 \\
2 & PNS & 3 & 9 \\
3 & Buruh Tani & 5 & 14 \\
4 & Petani & 4 & 11 \\
5 & Wirausaha & 35 & 100 \\
\hline & Total &
\end{tabular}

Mayoritas penduduk di Desa Coper dan Kutuwetan bekerja dibidang pertanian, namun banyak kader yang masih memiliki lahan pertanian sendiri dan menggarap sawahnya sendiri. Pekerjaan wirausaha sendiri adalah usaha berdagang, mayoritas berdagang warung skala kecil maupun besar. Usaha berdagangnya sendiri juga dilakukan dirumah kader masing-masing dan hanya sebagian kecil yang berdagang diluar dari rumahnya. Kader yang menjadi PNS hanya satu orang dari 35 kader yang ada. Pekerjaan ini juga hanya bekerja pada kantor desa dan sebagai pengawas dalam kesejahteraan masyarakat pada bidang kesehatan.

\section{Lama Bekerja}

Berdasarkan data di lapang diperoleh sebesar $37 \%$ kader yang bekerja lebih dari 16 tahun, hal ini disebabkan oleh banyaknya kader yang memang sejak muda sudah terjun dalam dunia kader Posyandu. Terdapat 29\% kader yang sudah bekerja selama 5 tahun atau dengan kata lain, merupakan kader yang masih baru terlibat dalam kegiatan Posyandu, selanjutnya ada perbandingan yang sama yaitu $17 \%$ untuk kader yang bekerja selama 6-10 tahun dan 11-15 tahun. Perbandingan ini dilakukan untuk mengetahui apakah kader yang bekerja sudah cukup lama memiliki pengetahuan yang jauh lebih baik dibandingkan kader yang masih cukup muda bekerja di Posyandu.

Tabel 4 Jumlah dan persentase responden (jiwa) menurut lamanya menjadi kader Posyandu di Desa Coper dan Desa Kutuwetan tahun 2017.

\begin{tabular}{llcc}
\hline No & $\begin{array}{l}\text { Lama Menjadi } \\
\text { Kader }\end{array}$ & Jumlah & $\begin{array}{l}\text { Persentase } \\
(\%)\end{array}$ \\
\hline 1 & $\leq 5$ Tahun & 10 & 29 \\
2 & 6 - 10 Tahun & 6 & 17 \\
3 & 11-15 Tahun & 6 & 17 \\
4 & $\geq 16$ Tahun & 13 & 37 \\
\hline & Total & 35 & 100 \\
\hline
\end{tabular}

\section{Sikap Kader Posyandu}

\section{Kognisi}

Berdasarkan tabel 5, aspek kognisi yang dimiliki kader paling besar adalah indikator sedang yang mencapai $60 \%$. Hal ini menunjukkan bahwa kader sudah paham dan mengerti tugas pokok kader dan fungsi dari Posyandu. Penjelasan ini didapatkan dari beberapa pelatihan yang diselenggarakan. Pelatihan yang dilakukan juga menyangkut beberapa hal seperti programprogram kesehatan yang terbaik, dan pengembangan kapasitas dari kader tersebut. Hal ini menyebabkan kader mengetahui jadwal Posyandu dan kebutuhan-kebutuhan kader 
mampu mengerti tugas-tugas yang harus dilakukan. Selain itu, kader menyadari bahwa kesehatan merupakan hal yang sangat penting dalam sebuah keluarga. Perannya sebagai seorang kader sudah dipahami dan merupakan suatu bentuk sukarela yang dilakukan seseorang untuk membangun kualitas hidup yang baik melalui Posyandu.

Tabel 5 Jumlah dan persentase responden (jiwa) dalam tingkat kognisi di Desa Coper dan Desa Kutuwetan.

\begin{tabular}{lrr}
\hline Kognisi & $\mathrm{n}$ & $\%$ \\
\hline Rendah & 7 & 20 \\
Sedang & 21 & 60 \\
Tinggi & 7 & 20 \\
\hline Total & 35 & 100 \\
\hline
\end{tabular}

Namun masih ada beberapa kader yang memiliki tingkat kognisi yang masih rendah yaitu sebesar $20 \%$. Hal ini disebabkan oleh masih kurangnya pemahaman kader mengenai tugas dan peran yang dimiliki. Biasanya kader yang masih memiliki pengalaman kerja yang masih sedikit atau kader masih baru terlibat dalam kegiatan Posyandu sehingga tingkat pemahanan dan skema yang dimiliki kader masih cukup rendah. Terdapat $20 \%$ kader pula yang memiliki tingkat kognisi yang cukup tinggi. Hal ini juga disebabkan oleh kemampuan yang dimiliki kader sudah sangat baik, skema yang dimiliki kader sudah sangat baik, serta kesadaran akan tanggung jawab yang dimiliki kader sudah sangat baik.

\section{Afeksi}

Berdasarkan tabel 6, diketahui bahwa sebagian kader memiliki tingkat afeksi yang sudah cukup baik yaitu sebesar 74,3\%. Kader memiliki emosional yang cukup baik terhadap Posyandu. Melalui tugas, tanggung jawab, dan pengetahuan yang dimiliki kader mampu menilai baik dan buruknya dari kualitas Posyandu. Selain itu ada beberapa kader yang sudah memiliki kemauan yang cukup tinggi yaitu sebesar $17,1 \%$ yang mengindikasikan bahwa kader sudah memiliki penilaian yang sangat baik terhadap Posyandu. Hal ini ditunjukkan dengan perasaan kader yang cukup baik terhadap lingkungan kerjanya. Namun ada $8,6 \%$ kader yang memiliki tingkat emosional yang rendah. Hal ini disebabkan oleh adanya dasar motivasi karena tuntutan keluarga seorang perangkat desa.

Tabel 6 Jumlah dan persentase responden (jiwa) dalam tingkat afeksi di Desa Coper dan Desa Kutuwetan tahun 2017.

\begin{tabular}{lrr}
\hline Afeksi & $\mathrm{n}$ & $\%$ \\
\hline Rendah & 3 & 8,6 \\
Sedang & 26 & 74,3 \\
Tinggi & 6 & 17,1 \\
\hline Total & 35 & 100 \\
\hline
\end{tabular}

\section{Konasi}

Berdasarkan tabel 7, diketahui bahwa 68,6\% responden yang memiliki sikap dalam aspek konasi yang sedang dan 14,3\% responden yang memiliki sikap konasi yang tinggi. Hasil tinggi tersebut ditunjukkan dengan kemampuan dan keinginan kader dalam bentuk tindakan. Hal tersebut juga ditunjukkan dengan keterlibatan kader yang cukup tinggi. Namun 17,1\% kader memiliki tingkat konasi yang rendah diakibatkan oleh waktu yang dimiliki kader tidak banyak dan kesadaran mengenai tugas dan tanggung jawabnya belum sepenuhnya dipahami oleh kader.Sikap ini dapat terlihat selama kader bekerja di Posyandu.

Tabel 7 Jumlah dan persentase responen (jiwa) dalam tingkat konasi di Desa Coper dan Desa Kutuwetan 2017.

\begin{tabular}{lrr}
\hline Konasi & $\mathrm{n}$ & $\%$ \\
\hline Rendah & 6 & 17,1 \\
Sedang & 24 & 68,6 \\
Tinggi & 5 & 14,3 \\
\hline Total & 35 & 100 \\
\hline
\end{tabular}

Pengalaman dan kemampuan melalui tindakan merupakan bentuk dari aspek konasi ini. Kader mengerti dan paham mengenai tanggung jawab yang diberikan. Hal ini dibuktikan bahwa sebagian besar kader sudah mau melakukan tugas yang diberikan berdasarkan diskusi bersama. Sebagian besar kader juga sudah mampu menyadari mengenai pentingnya kehadiran mereka dalam kegiatan Posyandu. Hal ini juga ditunjukkan dengan kader juga mau terlibat dalam kegiatan Posyandu yang bersifat dadakan atau hadir dalam suatu kegiatan yang tidak 
terjadwal. Kader juga menyukai kegiatan Posyandu, karena lingkungannya yang sangat baik dan hubungan yang dibina oleh para kader sangat baik. Sebagian kader sudah merasa nyaman dengan lingkungan kerja tersebut karena karakteristik yang mereka miliki sama dan hubungan antar kader dengan peserta Posyandu sudah cukup baik dan dekat.

\section{Motivasi Kerja Kader Posyandu}

\section{Intrinsik}

Berdasarkan tabel 8, menunjukkan bahwa sebagian besar masyarakat di Desa Coper dan Desa Kutuwetan yang terlibat menjadi seorang kader memiliki kesadaran akan dirinya sendiri yang cukup beragam. Terdapat $62,9 \%$ kader memiliki motivasi intrinsik yang cukup baik atau sedang. Hal ini disebabkan oleh adanya dominasi dari faktor ekstrinsik pula. Selain itu terdapat $22,9 \%$ kader yang memiliki motivasi intrinsik yang cukup rendah. Hal ini disebabkan dorongan terbesar yang dimiliki berasal dari luar diri sendiri atau lingkungan. Adanya ajakan teman-teman, rasa kepercayaan juga merupakan bentuk dorongan dari luar. Selanjutnya terdapat $14,3 \%$ kader yang memiliki motivasi intrinsik yang cukup tinggi yang menunjukkan bahwa kader memiliki dorongan dari dalam diri sendiri yang cukup tinggi. Hal ini menunjukkan bahwa keinginan menjadi seorang kader tidak dalam keadaan terpaksa.

Tabel 8 Jumlah dan persentase responden (jiwa) menurut tingkat motivasi intrinsik di Desa Coper dan Desa Kutuwetan tahun 2017.

\begin{tabular}{lrr}
\hline Intrinsik & $\mathrm{n}$ & $\%$ \\
\hline Rendah & 8 & 22,9 \\
Sedang & 22 & 62,9 \\
Tinggi & 5 & 14,3 \\
\hline Total & 35 & 100 \\
\hline
\end{tabular}

Banyak kader yang menyadari bahwa ternyata lingkungannya membutuhkan dirinya untuk terlibat dalam kegiatan Posyandu. Namun tidak seluruh kader termotivasi atas kesadaran diri sendiri, ada beberapa kader yang memang mengharuskan untuk terlibat langsung dengan kegiatan Posyandu. Seperti istri dari perangkat desa yang secara tidak langsung harus terlibat dalam kegiatan Posyandu.

Dorongan motivasi dari diri sendiri nyatanya terbukti untuk semua kader di Desa Coper maupun Desa Kutuwetan. Meskipun beberapa kader memang harus dituntut untuk bekerja karena suami adalah perangkat desa, hal ini membuat kader menyadari dirinya sendiri untuk bisa membantu juga dalam bentuk partisipatif. Bentuk partisipatif ini salah satunya ikut serta dalam beberapa kegiatan kesehatan Posyandu, seperti penyuluhan bagi masyarakat dan pelatihan bagi kader. Seperti keterlibatan kader dalam kegiatan senam ibu hamil. Dengan kesadaran sendiri, kader hadir untuk mendampingi dan membantu jalannya kegiatan hingga selesai. Hal ini mereka sadari dan mereka tidak merasa tertekan atau secara sukarela membantu kegiatan tersebut.

\section{Ekstrinsik}

Motivasi ekstrinsik nyatanya dilihat dari beberapa faktor yaitu kondisi kerja yang dimiliki kader, fasilitas yang dimiliki Posyandu, hubungan sosial yang dibangun, insentif yang diterima kader, dan pelatihan bagi seluruh kader Posyandu. Kader di Desa Coper dan Desa Kutuwetan memiliki motivasi ekstrinsik yang cukup beragam.

Tabel 9 Jumlah dan persentase responden (jiwa) menurut tingkat motivasi ekstrinsik di Desa Coper dan Desa Kutuwetan tahun 2017

\begin{tabular}{lrr}
\hline Ekstrinsik & $\mathrm{n}$ & $\%$ \\
\hline Rendah & 5 & 14,3 \\
Sedang & 22 & 62,9 \\
Tinggi & 8 & 22,9 \\
\hline Total & 35 & 100 \\
\hline
\end{tabular}

Beberapa kader memiliki motivasi ekstrinsik yang cukup rendah yaitu sebesar $14,3 \%$ yang disebabkan oleh fasilitas yang dimiliki Posyandu masih cukup buruk dan pelatihan yang dilaksakan bersifat tidak merata. Selanjutnya terdapat $62,9 \%$ kader yang memiliki motivasi ekstrinsik yang cukup baik dan $22,9 \%$ kader memiliki tingkat motivasi ekstrinsik yang sangat tinggi. Hal ini menunjukkan bahwa dorongan dari lingkungan 
memiliki pengaruh terhadap keputusan kader dalam menerima pekerjaan. Selain itu, lingkungan kerja yang sesuai membuat kader merasa nyaman dengan pekerjaan yang dilakukan. Beberapa kader yang memiliki motivasi ekstrinsik yang rendah disebabkan oleh tuntutan suami yang menjadi seorang perangkat desa yang menyebabkan mereka harus ikut serta pula dengan kegiatan Posyandu. Selain itu adanya dorongan dari lingkungan juga memotivasi kader selama ini. Kader Posyandu di Desa Coper maupun Desa Kutuwetan, senang dengan lingkungan kerja mereka.

\section{Kinerja Kader Posyandu}

\section{Kerjasama}

Berdasarkan tabel 9, dapat menunjukkan bahwa kerjasama yang dilakukan kader terbilang beragam. Sebanyak $60 \%$ kader memiliki tingkat kerjasama yang cukup baik. Hal ini ditunjukkan dengan hubungan yang dibangun sudah cukup baik dan komunikasi yang dilakukan sudah cukup baik kepada sesama kader, bidan atau perawat desa, serta peserta Posyandu.

Tabel 9 Jumlah dan persentase responden (jiwa) berdasarkan tingkat kerjasama di Desa Coper dan Desa Kutuwetan tahun 2017.

\begin{tabular}{lrr}
\hline Kerjasama & $\mathrm{n}$ & $\%$ \\
\hline Rendah (buruk) & 6 & 17,1 \\
Sedang & 21 & 60,0 \\
Tinggi (baik) & 8 & 22,9 \\
\hline Total & 35 & 100 \\
\hline
\end{tabular}

Selanjutnya $17,1 \%$ kader memiliki kemampuan kerjasama yang buruk. Hal ini biasanya ditunjukkan dengan kader yang bekerja sendiri atau cenderung tidak mengerti dengan tugas yang dimilikinya. Selain itu terdapat $22,9 \%$ kader yang memiliki kemampuan kerjasama yang sangat baik. Hubungan kerjasama terbilang cukup baik dalam kegiatan Posyandu. Hampir sebagian besar kader sudah mampu mengorganisir diri dan mampu membantu satu sama lain. Sebagian besar kader juga sudah mampu untuk saling membantu dengan sesama kader Posyandu. Sistem lima meja membuat para kader memiliki satu tugas pada setiap meja.

\section{Tingkat Kehadiran}

Berdasarkan hasil dilapang kader di Desa Coper dan Desa Kutuwetan memiliki keinginan untuk hadir dalam kegiatan penyuluhan dan pelatihan cukup baik. Kader mau hadir dalam kegiatankegiatan yang mengikutsertakan dirinya. Para kader menyadari pentingnya mengikuti kegiatan pelatihan yang ada, mereka menyadari keterbatasan pengetahuan yang mereka miliki dan mereka ingin menambahkan wawasan mereka mengenai kesehatan masyarakat. Selain itu, dengan adanya pelatihan kader juga mampu mengetahui informasi-informasi terbaru seputar kesehatan. Maka dari itu, kehadiran kader pada setiap kegiatan Posyandu di kedua desa dinilai sangat baik.

Tabel 10 Jumlah dan persentase responden (jiwa) berdasarkan tingkat kehadiran di Desa Coper dan Desa Kutuwetan dalam kegiatan Posyandu tahun 2017.

\begin{tabular}{lrr}
\hline Tingkat Kehadiran & $\mathrm{n}$ & $\%$ \\
\hline Rendah (buruk) & 5 & 14,3 \\
Sedang & 27 & 77,1 \\
Tinggi (baik) & 3 & 8,6 \\
\hline Total & 35 & 100 \\
\hline
\end{tabular}

Tingkat kehadiran kader sangat beragam. Sebanyak $77,1 \%$ kader memiliki tingkat kehadiran yang cukup baik. Hal ini menunjukkan bahwa kader mampu hadir sesuai pada waktunya dan hadir dalam setiap kegiatan. Selanjutnya $14,3 \%$ kader memiliki tingkat kehadiran yang rendah. Ada beberapa alasan kader memiliki tingkat kehadiran yang rendah yaitu waktu yang digunakan diutamakan untuk keluarga terlebih dahulu, selanjutnya perubahan jadwal Posyandu yang membuat kader yang sudah memiliki agenda tidak mampu untuk hadir dalam kegiatan Posyandu. Selain itu 8,6\% kader memiliki tingkat kehadiran yang cukup tinggi.

Kehadiran kader saat kegiatan Posyandu berlangsung juga cukup baik. Sebagian kader sudah paham mengenai pentingnya kehadiran dalam setiap kegiatan Posyandu. Kader juga hadir hingga kegiatan Posyandu berakhir. Selain kegiatan Posyandu, kader juga hadir dalam 
kegiatan pra-Posyandu dan juga kegiatan penyuluhan dan pelatihan.

\section{Pemanfaatan Waktu}

Kader yang memiliki pemanfaatan waktu yang cukup yaitu sebesar $62,9 \%$. Pemanfaatan waktu tersebut dilihat dari manajemen waktu yang dimiliki kader selama menjalankan tugas dan tanggung jawabnya. Selain itu 22,9\% kader sudah memiliki tingkat pemanfaatan waktu yang sangat baik atau dengan kata lain manajemen waktu yang dimiliki kader sudah teratur. Terdapat $14,3 \%$ pula kader yang memiliki pemanfaatan waktu yang buruk. Hal ini disebabkan oleh adanya kegiatan mendesak kader saat kegiatan Posyandu dilaksanakan, namun hal ini bukan merupakan masalah dalam upaya kinerja yang dilakukan kader.

Tabel 11 Jumlah dan persentase responden (jiwa) berdasarkan tingkat pemanfaatan waktu di Desa Coper dan Desa Kutuwetan tahun 2017

\begin{tabular}{lrr}
\hline Pemanfaatan Waktu & $\mathrm{n}$ & $\%$ \\
\hline Rendah (buruk) & 5 & 14,3 \\
Sedang & 22 & 62,9 \\
Tinggi (baik) & 8 & 22,9 \\
\hline Total & 35 & 100 \\
\hline
\end{tabular}

Rata-rata kegiatan Posyandu dimulai pada pukul 08.00 dan selesai pukul 12.00 dan dilanjutkan dengan evaluasi terhadap kegiatan Posyandu. Kader-kader di Desa Coper dan Desa Kutuwetan memiliki kemampuan bekerja tepat waktu sudah cukup baik meskipun saat pengumpulan tugas kader masih memiliki kelemahan. Hal ini berdampak pada ketepatan waktu kader dalam pengumpulan tugas terakhir atau bahan evaluasi. Beberapa kader masih memiliki kemampuan penyelesaian tugas yang masih kurang baik. Hubungan baik antar kader nyatanya memberikan pengaruh yang cukup baik. Salah satu contohnya dalam penyelesaian tugas, beberapa kader yang kesulitan dalam mengerjakan tugasnya akan dibantu dengan kader yang sebelumnya sudah menyelesaikan tugasnya. Hal ini menunjukkan bahwa kader memiliki kemampuan untuk membantu kader lainnya cukup baik dan akan memberikan pengaruh pula terhadap manajemen waktu setiap kader tersebut. Mayoritas kader hadir hingga rapat evaluasi selesai, namun ada beberapa kader yang biasanya harus izin karena ada kepentingan yang lain. Hal ini menunjukkan bahwa sebagian besar kader terlibat hingga kegiatan Posyandu berakhir

\section{Kualitas Kerja}

Berdasarkan tabel 12 dapat terlihat bahwa sebanyak $57,1 \%$ kader sudah memiliki kualitas kerja yang cukup baik. Kader cukup sanggup dan mengerti untuk melakukan pelayanan kepada peserta Posyandu. Selanjutnya 22,9\% kader memiliki kualitas kerja yang masih buruk. Hal ini didasari oleh kemampuan kader yang masih cukup rendah dan pengalaman kader yang masih sangat kurang. Selain itu 20\% kader memiliki kualitas kerja yang cukup baik. Kader mampu sabar terhadap balita yang sulit untuk ditimbang atau dicek kesehatannya.

Tabel 12 Jumlah dan persentase responden (jiwa) berdasarkan tingkat kualitas kerja di Desa Coper dan Desa Kutuwetan tahun 2017

\begin{tabular}{lrr}
\hline Kualitas Kerja & $\mathrm{n}$ & $\%$ \\
\hline Rendah (buruk) & 8 & 22,9 \\
Sedang & 20 & 57,1 \\
Tinggi (baik) & 7 & 20,0 \\
\hline Total & 35 & 100 \\
\hline
\end{tabular}

Hal ini menunjukkan bahwa sebagian besar kader memiliki tingkat kesabaran dalam melayani masyarakat cukup baik. Kemampuan kader yang lain yaitu kader mampu berkomunikasi dengan baik dengan peserta Posyandu. Komunikasi yang baik juga akan menentukan peserta Posyandu akan hadir kembali atau tidak pada kegiatan Posyandu selanjutnya. Nyatanya, sebagian besar kader mampu berkomunikasi dengan baik kepada peserta Posyandu. Kesamaan bahasa dan budaya merupakan faktor pendorong dalam kemudahan komunikasi. Banyak ibu balita yang bercerita mengenai bagaimana keseharian dari anaknya hingga terjadi masalah seperti gizi buruk dan gizi kurang namun batasan kader hanya sebagai perantara yang nantinya akan dikonsultasikan kembali dengan bidan dan perawat desa.

\section{Kuantitas Kerja}


Beberapa hal dapat mengukur kuantitas kerja seseorang seperti kemampuan dalam melayani, berapa lama waktu yang digunakan untuk bekerja, berapa banyak output yang diberikan. Pada penelitian kuantitas kerja dilihat dari seberapa besar kader mampu memberikan kontribusi kepada Posyandu. Sebagian besar kader mampu untuk melayani peserta Posyandu dengan baik. Hal ini ditunjukkan dengan komunikasi yang dilakukan cukup baik dan kesamaan bahasa yang mempermudah jalannya kegiatan Posyandu. Selain itu beberapa kader memberitahukan kegiatan Posyandu kepada seluruh peserta Posyandu selanjutnya. Beberapa kader juga melakukan kunjungan rumah peserta Posyandu. Hal ini dilakukan kepada beberapa peserta Posyandu yang tidak hadir dan perlu pemberian motivasi. Selain kunjungan motivasi, kader juga melakukan kunjungan bagi balita yang berkebutuhan khusus, atau balita dibawah garis merah. Kunjungan ini biasanya dalam hal pemberian susu tambahan bagi balita berkebutuhan khusus. Hal ini menunjukkan bahwa kader memberikan kontribusi besar dalam pembangunan kesehatan di desa.

Tabel 13 Jumlah dan persentase responden (jiwa) berdasarkan tingkat kuantitas kerja di Desa Coper dan Desa Kutuwetan tahun 2017

\begin{tabular}{lrr}
\hline Kuantitas Kerja & $\mathrm{n}$ & $\%$ \\
\hline Rendah (buruk) & 4 & 11,4 \\
Sedang & 27 & 77,1 \\
Tinggi (baik) & 4 & 11,4 \\
\hline Total & 35 & 100 \\
\hline
\end{tabular}

Jumlah kader pada setiap pos Posyandu tidak banyak dan harus memiliki kemampuan mengatur tugas dan waktu dengan baik. Sebagian besar kader dikedua desa memiliki 77,1\% kader yang memiliki kuantitas kerja yang cukup baik. Selain itu $11,4 \%$ kader memiliki kuantitas kerja yang masih buruk. Hal ini disebabkan oleh lemahnya pemahaman kader dan juga pengalaman yang dimiliki kader. Selanjutnya $11,4 \%$ kader memiliki kuantitas kerja yang sangat baik. Hal ini terlihat dari kader yang memiliki daya tanggap yang tinggi dalam menjalankan tugasnya.

\section{Hubungan sikap dengan motivasi kerja kader posyandu}

Hasil pengujian rank spearman menunjukkan bahwa terdapat hubungan signifikan antara sikap dengan motivasi kerja para kader Posyandu dengan hasil uji korelasi sebesar 0,390 dengan nilai korelasi signifikan 0,05 . Hal ini menunjukkan dari hasil uji korelasi dalam penelitian ini menerima hipotesis yang menduga bahwa terdapat hubungan antara sikap dengan motivasi kerja yang dilakukan kader Posyandu.

Hal ini dibuktikan dengan konsistensi kader selama bekerja, yaitu sikap peduli sesama masyarakat dan suka menolong. Selama kader bekerja motivasi bekerja didasari oleh dorongan dari lingkungan dan diri sendiri. Sikap peduli kader didasari karena motivasi kader tersebut senang dengan menolong orang lain. Kebutuhan masyarakat akan dirinya juga merupakan motivasi kader dalam menjalankan perannya di Posyandu. Hal ini akan memicu sikap positif yang diberikan kader kepada para peserta Posyandu. Berikut ini adalah hasil tabulasi silang sikap dengan motivasi kerja kader Posyandu.

Kader mampu mengenal keadaan masyarakat bisa membantu secara aktif dengan mendekatkan kebutuhan-kebutuhan pelayanan dengan ciri-ciri spesifik masyarakat desanya. Keadaan ini membuat kader mampu memotivasi peserta Posyandu dengan menggunakan pendekatan secara personal. Kader selalu mengajak peserta kader untuk selalu hadir dalam kegiatan Posyandu dan penyuluhan-penyuluhan yang diselenggarakan Puskesmas. Sikap simpati terhadap kesehatan masyarakat desa juga ditunjukkan dengan kegiatan diluar Posyandu. Salah satunya dengan melakukan kunjungan ke rumah-rumah yang memiliki balita dibawah garis merah atau peserta Posyandu yang tidak hadir pada kegiatan Posyandu.

\section{Hubungan sikap dengan kinerja kader posyandu}

Hasil uji rank Spearman menunjukkan uji korelasi sebesar 0,322 pada nilai korelasi signifikan 0,05 , yang menunjukkan bahwa sikap kader berhubungan dengan kinerja yang dimiliki kader. Hasil uji korelasi diatas menunjukkan bahwa penelitian ini menerima hipotesis yang 
menduga terdapat hubungan antara sikap dengan kinerja kader Posyandu.

Pengalaman yang cukup lama memengaruhi tingkat dari pengetahuan kader. Rata-rata kader sudah bekerja diatas 5 tahun yang dapat diindikasikan kader sudah mampu mandiri dalam mengerjakan tugasnya. Pengalaman yang dimiliki ini mampu menunjukkan bagaimana kader merespon dengan baik fenomena kesehatan yang ada di lingkungannya. Sikap inilah yang dimiliki berdasarkan pengalaman kader selama bekerja menjadi unit pelayanan masyarakat.

Kader Posyandu kerap dijadikan rujukan oleh warga sekitar tempat tinggal mereka untuk berdiskusi terkait masalah kesehatan. Tidak semata kesehatan ibu dan anak. Hal ini karena masyarakat melihat kedekatan kader dengan bidan/perawat desa sehingga beranggapan bahwa kader memiliki pengetahuan yang memadai terkait masalah kesehatan.

Waktu pelaksanaan Posyandu yang cukup singkat, membuat kader harus mampu menyelesaikan tugas-tugas yang sudah diberikan masing-masing. Oleh sebab itu dibutuhkan suatu kerjasama yang baik dalam kelompok. Sikap kader dalam bekerjasama di kelompok pos Posyandu sangat baik. Kader mampu saling membantu satu sama lainnya, dan semaksimal mungkin kader mengerjakan tgas yang diberikan. Efektifitas dan efisiensi waktu digunakan sangat baik oleh kader, bahkan waktu pelaksanaan Posyandu bisa lebih cepat selesai dari waktu yang ditentukan.

\section{Hubungan motivasi kerja dengan kinerja kader posyandu}

Sebagian besar kader dengan sukarela bekerja untuk menghidupkan Posyandu karena merasa bertanggung jawab terhadap lingkungannya. Hal ini ditunjukkan dengan hasil uji korelasi antara motivasi kerja dengan kinerja kader Posyandu. Hasil korelasi tersebut menunjukkan 0,375 pada nilai korelasi signifikan 0,05 yang menyatakan bahwa terdapat hubungan signifikan antara motivasi kerja dengan kinerja pada kader Posyandu. Hasil dari penelitian ini menerima hipotesis yang menyatakan diduga terdapat hubungan motivasi kerja dengan kinerja kader Posyandu.
Hubungan signifikan ini dapat ditunjukkan dengan seorang kader yang memiliki motivasi yang tinggi maka kinerja kader tersebut akan semakin baik. Hal ini dilandasi pula karena motivasi kader yang merupakan suatu kumpulan perilaku yang memberikan landasan bagi kader untuk bertindak dalam suatu cara yang diarahkan kepada tujuan tertentu.

Lingkungan kerja dapat memicu kinerja yang baik untuk kader. Kenyamanan selama kader bekerja dinilai dapat meningkatkan motivasi bekerja kader. Fasilitas-fasilitas yang cukup memadai dapat membuat kader merasa tidak kesulitan dalam menjalankan tugasnya seperti peralatan tulis, alat timbang, kursi, meja, makanan MPT, serta mainan anak-anak sangat dibutuhkan selama kegiatan Posyandu berlangsung.

Rekan kerja yang sudah mengenal satu sama lain membuat kader mampu termotivasi dalam bekerja karena kesamaan tujuan yaitu membantu Posyandu untuk menciptakan kualitas kesehatan yang baik di desa. Selama kader bekerja, tidak ada kesulitan yang terjadi karena kerjasama yang dibangun dan kepercayaan satu sama lainnya. Kesulitan-kesulitan yang terjadi nyatanya dapat terselesaikan dengan mengerjakan bersama-sama dan saling membantu satu sama lainnya. Oleh sebab itu, hubungan sesama kader sangat baik, jika satu kader tidak hadir maka akan menyulitkan kegiatan Posyandu. Maka dari itu kader menyadari bahwa kehadirannya merupakan hal penting dalam menunjuang kegiatan Posyandu.

Bentuk pelatihan atau penyuluhan merupakan hal penting dalam menunjang kualitas kerja seorang kader. Pelatihan yang dilakukan memang tidak sepenuhnya dilakukan serentak kepada seluruh kader. Terdapat sistem bergilir untuk setiap kader dalam pelatihan yang dilaksanakan. Penyelenggaran pelatihan adalah Puskesmas yang mewajibkan setiap desa mengirimkan perwakilan dari setiap pos untuk hadir dalam pelatihan yang diselenggarakan. Guna dari pelatihan ini adalah untuk melatih dan mempraktikkan kegiatan Posyandu, sedangkan kader- kader yang lama untuk memberikan kegiatan yang baru agar posyandu lebih variatif. 
Kegiatan Posyandu hakekatnya mendekatkan pelayanan kesehatan kemasyarakat dan pada akhirnya dapat meningkatkan derajat kesehatan masyarakat. Oleh sebab itu, dibutuhkan dukungan dari masyarakat agar kader termotivasi untuk selalu hadir dalam kegiatan Posyandu dan melaksanakan tugasnya dengan baik. Dukungan dari orang sekitar nyatanya mampu meningkatkan motivasi bekerja kader. Kepercayaan yang diberikan masyarakat kepada para kader dapat meningkatkan semangat para kader dalam bekerja dan bertahan di Posyandu selama bertahun-tahun.

\section{KESIMPULAN DAN SARAN}

\section{Simpulan}

Kontribusi yang diberikan kader tidak terlepas dari dorongan motivasi yang memengaruhi. Upaya kontribusi ini dapat dilihat dengan perilaku atau sikap kader terhadap suatu objek. Objek tersebut adalah kegiatan Posyandu yang dilakukan setiap bulannya. Terdapat hubungan antara sikap dengan motivasi kerja pada kader Posyandu. Hal ini ditunjukkan dengan uji korelasi sebesar 0,322 yang menunjukkan bahwa semakin baik sikap kader, maka semakin tinggi pula motivasi kerja yang dimiliki kader. Penelitian ini menunjukkan bahwa menerima hipotesis yang menyatakan terdapat hubungan antara sikap dengan motivasi kerja kader Posyandu.

Kualitas kader sangat menentukan dalam usaha meningkatkan kualitas pelayanan yang dilaksanakan. Sikap kader yang dapat menentukan kinerja kader selama bekerja di Posyandu. Hal ini dibuktikan dengan uji korelasi antara sikap dengan kinerja yang mencapai 0,390 yang membuktikan bahwa adanya hubungan dari keduanya. Penelitian ini membuktikan bahwa menerima hipotesis tentang diduga terdapat hubungan anatara sikap dengan kinerja kader Posyandu.

Konsekuensi menjadi seorang kader tidak mudah, karena kader memiliki tugas untuk menyukseskan program kerja Puskesmas dengan cara mengihidupkan Posyandu. Oleh sebab itu dibutuhkan motivasi kerja yang tinggi agar kinerja yang diberikan bisa maksimal. Adanya hubungan motivasi kerja dengan kinerja kader ini terbukti dengan uji korelasi rank Spearman sebesar 0,375. Hal ini menunjukkan bahwa menerima hipotesis yang menyatakan bahwa terdapat hubungan antara motivasi kerja dengan kinerja kader Posyandu.

\section{Saran}

Berdasarkan hasil dari penelitian ini, ada beberapa saran yang diajukan. Pertama, perlunya pelatihan yang dilakukan secara menyeluruh untuk seluruh kader. Kedua, perlunya pemahaman bagi seorang kader untuk bisa memberi contoh kepada masyarakat mengenai hidup sehat, karena masyarakat memiliki kepercayaan kepada kader Posyandu bahwa mereka mampu untuk memberikan contoh hidup sehat bagi keluarga. Ketiga, perlu adanya penjadwalan yang lebih jelas mengenai pengumpulan hasil rekap kegiatan Posyandu oleh bidan dan perawat desa agar kader mampu mengumpulkan tugasnya tepat waktu. Keempat, perlu adanya pengawasan, pengaturan dan pemberian motivasi agar kader mampu meningkatkan lagi kualitas layanan kesehatan. Kelima, perlu adanya suatu bentu pengakuan atau penghargaan kepada kader secara formal guna meningkatkan motivasi dan semangat kerja. Keenam, perlunya kemandirian kader dalam menjalankan tugasnya agar kader mampu menjalankan tugasnya masing-masing dan mampu menyelesaikan secara tepat waktu.

\section{DAFTAR PUSTAKA}

Darmawan SE. 2009. Tinjauan Kebijakan Terkait Pengelolaan Posyandu Sebagai Masukan dalam Perumusan Peran dan Tanggungjawab Departemen Kesehatan dalam Pengelolaan Posyandu. Depok [ID]: Departemen AKK FKM UI.

Depkes RI. 2005. Pedoman Kegiatan Kader Posyandu. Jakarta [ID]: Departemen Kesehatan RI.

Depkes RI. 2006. Posyandu. Jakarta[ID]: Departemen Kesehatan RI.

Depkes RI. 2011. Usia Harapan Hidup di Indonesia. Jakarta [ID]:cDepartemen Kesehatan RI.

Harihanto. 2001. Persepsi, Sikap, dan Perilaku Masyarakat Terhadap Air Sungai (Kasih di Das Kaligarang, Jawa Tengah)[disertasi]. Bogor [ID]: Institut Pertanian Bogor.

Listiani L. 2012. Analisis Model Sikap Perilaku Terencana: Pengaruh Sikap Konsumen Terhadap Intensi dan Konsumsi Pangan Organik [skripsi]. Bogor [ID]: Institut Pertanian Bogor. 
Sengkey S, Kandou G, Pangemanan J. 2015. Analisis Kinerja Kader Posyandu di Puskesmas Paniki Kota Manado [jurnal]. [diunduh pada 2 Januari 2017]. Dapat diunduh pada: http://ejournal.unsrat.ac.id/ index.php/jiku/article/download/7857/7421.

Simanjuntak M. 2012. Karakteristik Sosial Demografi Dan Faktor Pendorong Peningkatan Kinerja Kader Posyandu [internet]. [diunduh 26 September 2016]. Dapat diunduh pada: https://mikroskil.ac.i d/e.jurnal/index.php/jwem/article/view/68/57.

Simanjuntak M, Amanah S, Tjitropranoto, et.al .2012. Kepuasan Kerja Kader Posyandu di Desa Ciherang, Kecamatan Dramaga [internet]. [diunduh pada 26 September 2016]. Dapat diunduh pada: http://jesl. journal.ipb.ac.id/index.php/jupe/article/view/9 $857 / 7717$.

Sudarsono. 2010. Hubungan Sikap dan Motivasi dengan Kinerja Kader Posyandu di Wilayah Kerja Puskemas Talun Kabupaten Blitar [tesis].[diunduh pada 2 Januari 2017]. Dapat diunduh pada: https://eprints .uns.ac.id/10234/1/186501111201109411.pdf.

Suhartini, Khoiri A, Eri Witcahyo. 2014. Faktor Yang Berhubungan Dengan Kinerja Kader Dalam Kegiatan Program Perencanaan Persalinan dan Pencegahan Komplikasi (P4K) di Puskesmas Semboro Tahun 2013 [jurnal]. Artikel Ilmiah Hasil Penelitian Mahasiswa 2014. Jember [ID]: Universitas Jember.

Sumarwan U. 2011. Perilaku Konsumen: Teori dan Penerapannya dalam Pemasaran. Jakarta [ID]: Ghalia Indonesia.

Wijaya IMK. 2013. Pengetahuan, Sikap, dan Motivasi Terhadap Keaktivan Kader dalam Pengendalian Tuberkulosis [internet]. [diunduh 26 September 2016]. Dapat diunduh pada:http://journal.unnes.a c.id/ju/index.php/kemas/article/view/2637/270 
Kusumawardani \& Muljono / Jurnal Sains Komunikasi dan Pengembangan Masyarakat 2(2): 223-238 